\title{
On the aorist in conditional antecedents
}

\author{
Bergül Soykan*
}

\begin{abstract}
This paper aims to render an explanation for the interpretations of the Turkish aorist when it occurs at the antecedent clause of a conditional. I argue that the aorist marker has two main interpretations in the main predicate position, namely the future-oriented and the characterizing ones. However, inside the antecedent clause, these readings are not readily accessible in the way that they are in the consequent clause, i.e., the main predicate of the conditional. I tackle this situation from two different perspectives and layout two proposals. Based on Kratzer's (1986, 1991) well-known restrictor analysis of conditionals, my first proposal is that the aorist marker is licensed in the antecedent clause only if the consequent clause has one of its matrix clause interpretations. Nonetheless, various examples allow the aorist marker in the antecedent even though the consequent clause has neither the future-oriented nor the characterizing interpretations. Therefore, I change my approach and make a final proposal that satisfactorily describes both the cases that conform to my initial proposal and the ones that do not. I propose that the aorist in the antecedent either sets the evaluation time of the consequent to the future, in line with Schulz's (2008) analysis or makes a quantification over situations, as von Fintel (1994) argues for.
\end{abstract}

Keywords. conditionals; the aorist marker; antecedent clause; consequent clause.

1. Introduction. The so-called aorist marker in Turkish has been examined by many (e.g., Göksel \& Kerslake, 2005; Kornfilt, 1997; Yavaş, 1979 a.o.) and sometimes has been analyzed as the Simple Present Tense in English (Kornfilt, 1997) whereas some others (Göksel \& Kerslake, 2005; Yavaş, 1979) deem it as an aspectual and a modal marker. However, Cinque (2001) refrains from discussing the aorist marker while tackling the tense, aspect, and modality affixes in Turkish due to not being certain about which head it might belong to in his study. As this controversy demonstrates, defining the functions of the aorist is not an easy task. ${ }^{1}$ Therefore, I focus on the interpretation(s) of the aorist rather than categorizing it as a tense, aspect, or modal marker for the current purposes. In terms of its interpretations, the aorist can be categorized under two distinct readings: the future-oriented and the characterizing (Yavaş, 1979). However, these readings seem to demonstrate some differences at the antecedent of a conditional compared to the consequent version. If the aorist selects its future-oriented reading in an antecedent clause, then the evaluation time of the consequent clause shifts to the future. On the other hand, if it chooses its characterizing reading, it quantifies over situations.

\footnotetext{
* I am grateful to Dr. Ömer Demirok for his great help in the process of writing and forming the ideas and the discussions in this study. Also, I would like to thank Elanur Sönmez for her support and aid in the felicity judgements of the many examples provided. Lastly, I thank the participants and the committee members at the TU+6 conference for their questions and comments and two reviewers who have helped me give the final version of my paper. This paper is largely based on the second chapter of MA thesis (Soykan, 2021). Author: Bergül Soykan, Boğaziçi University (bergul.soykan.25@gmail.com).

${ }^{1}$ An orthogonal point is that the label "aorist" itself is used to refer to past events or perfect aspect outside Turkish linguistics, such as in Ancient Greek or in other Indo-European languages.
} 
In Section 2, I first discuss what kind of interpretations the aorist suffix gets in the context of matrix sentences. Then, Section 3 expresses how an antecedent clause behaves differently from a consequent clause in conditional statements. This part illustrates that the antecedent clause demonstrates an embedded occurrence and hence it bears certain restrictions compared to the consequent clause. Section 4 is about the interpretations the aorist marker has when it appears in an antecedent clause of a conditional. Afterward, in Section 5, I provide a primary proposal for the issues discussed and continue with some challenges this proposal might have. In Section 6, I extend my proposal based on Schulz's (2008) approach to the Simple Present tense in English and von Fintel's (1994) analysis of quantifier domains and then conclude with some final remarks and discussion in Section 7.

2. The aorist in matrix clauses. The aorist marker can be used in many different contexts in Turkish, ranging from habitual actions of individuals to generic properties of classes and from predictions to offers and requests, as respectively exemplified from (1) to (5), (see Göksel \& Kerslake, 2005; Kornfilt, 1997; Yavaş, 1979 a.o.).

$\begin{array}{ll}\text { Elif her gün } & \text { koş-ar. } \\ \text { Elif every day } & \text { run- AOR } \\ \text { 'Elif runs every day.' } & \\ \text { Flamingo-lar } & \text { uç-ar. } \\ \text { flamingo-PL } & \text { fly- AOR } \\ \text { 'Flamingos fly.' } & \end{array}$

$\begin{array}{lll}\text { Şeyma } & \text { birazdan } & \text { gel-ir. } \\ \text { Şeyma } & \text { soon } & \text { come- AOR }\end{array}$

'Şeyma will come soon.'

$$
\begin{array}{ll}
\text { Çay al-Ir-m1-sin? } \\
\text { tea get- AOR-Q-2SG }
\end{array}
$$

'Would you like to have some tea?'

$\begin{array}{llll}\text { Bana } & \text { kalem-i } & \text { ver-ir-mi-sin } & \text { lütfen? } \\ \text { 1SG.DAT pencil-ACC } & \text { give-AOR-Q-2SG } & \text { please } & \\ \text { 'Would you please give me the pencil? } & & \text { (Request) }\end{array}$

However, I propose combining these different usages of the aorist marker under two main interpretations, namely characterizing and future-oriented, intended as descriptive labels at the moment. The characterizing interpretation can stand for both the habitual and generic readings since in both cases the sentences can be paraphrased as "it is the characteristic feature of $\mathrm{x}$ to do $y^{\prime \prime 2}$. The only difference here is that in the context of habitual sentences, we express the characteristic feature of an individual whereas generic sentences are mainly related to the characteristic features of a certain class (Göksel \& Kerslake, 2005). Likewise, the other readings in (3), (4), and (5) can be summed up into a future-oriented interpretation in general as they all refer to an action that might happen or is desired to happen in the future. ${ }^{3}$ I put aside the offer and request functions when considering the future-oriented interpretation for my study, hoping that they can

\footnotetext{
${ }^{2}$ It needs to be stated here that the aorist marker can only attach to verbal predicates, hence I will not focus on the nominal predicates.

${ }^{3}$ Yavaş (1979) also argues that the aorist has two main functions, one being the characterizing aspect and the other being the volitional modal. Inspired by her approach, I also make a similar categorization without assigning a label like "aspect" or "modal".
} 
be subsumed under the future-oriented reading with an appropriate account of the pragmatics involved.

In sum, for the beginning, I postulate that the aorist can be utilized either if we are referring to the characteristic events ${ }^{4}$ or if we are referring to future-oriented possibilities. In the next sections, I argue that these readings seem not accessible inside a conditional antecedent and try to explain its reasons.

3. The antecedent vs. the consequent clauses in conditionals. Even though the aorist marker can be seen in both the antecedent and the consequent clauses in conditional statements as in (6), it certainly does not have the same functions in both contexts mainly because the contexts are syntactically different from each other.

$$
\begin{array}{llll}
\text { Ela parti-ye } & \text { gel-ir-se, } & \text { onunla } & \text { tanış- } l r-\text { sin. } \\
\text { Ela party-DAT } & \text { come-AOR-COND } & \text { 3SG.COM } & \text { meet-AOR-2SG } \\
\text { 'If Ela comes to the party, you will meet her.' } &
\end{array}
$$

For instance, certain adverbials that are usually licensed by the aorist marker when it is in matrix sentences are not allowed when they are used inside the antecedent clause. The aorist marker in matrix sentences permits the use of speaker-oriented attitude adverbs such as bence 'in my opinion' or possibility adverbs such as muhtemelen 'probably' under its future-oriented possibility reading, as respectively shown by the examples (7) and (8). ${ }^{5}$

Şeyma

bence

birazdan

gel-ir.

Şeyma

in my opinion soon

come-AOR

'In my opinion, Şeyma will come soon.'

$\begin{array}{llll}\text { Şeyma } & \text { muhtemelen } & \text { birazdan } & \text { gel-ir. } \\ \text { Şeyma } & \text { probably } & \text { soon } & \text { come-AOR }\end{array}$

'Şeyma will probably come soon.'

On the other hand, they cannot occur inside conditional antecedents, as shown by (9) and (12).

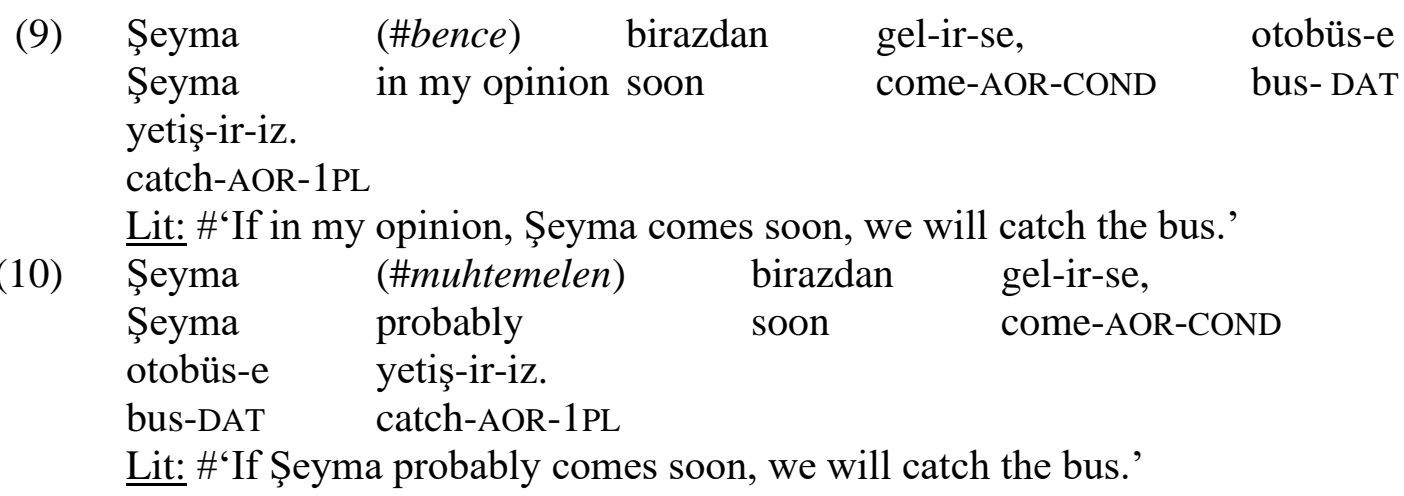

The reason for this situation is that the antecedent clause of a conditional statement is in fact an embedded clause. Moreover, as shown by (11) and (12), the consequent clause, contrary to the antecedent, behaves exactly like a matrix sentence in terms of licensing these adverbials, which provides further evidence for the fact that the antecedent and consequent clauses are different

\footnotetext{
${ }^{4}$ Göksel and Kerkslake (2005) uses "characteristic qualities" and Yavaş (1979) uses "characteristic or typical behaviour" to refer to the characterizing interpretation of the aorist. Here, I refer to it as "characteristic events".

${ }^{5}$ The important point here is that these are allowed at the matrix level but not at the embedded one.
} 
from each other in terms of their structure. ${ }^{6}$ The aorist marker per se does not create this difference but it does matter whether it is in the antecedent or the consequent of a conditional when it comes to its interpretation.

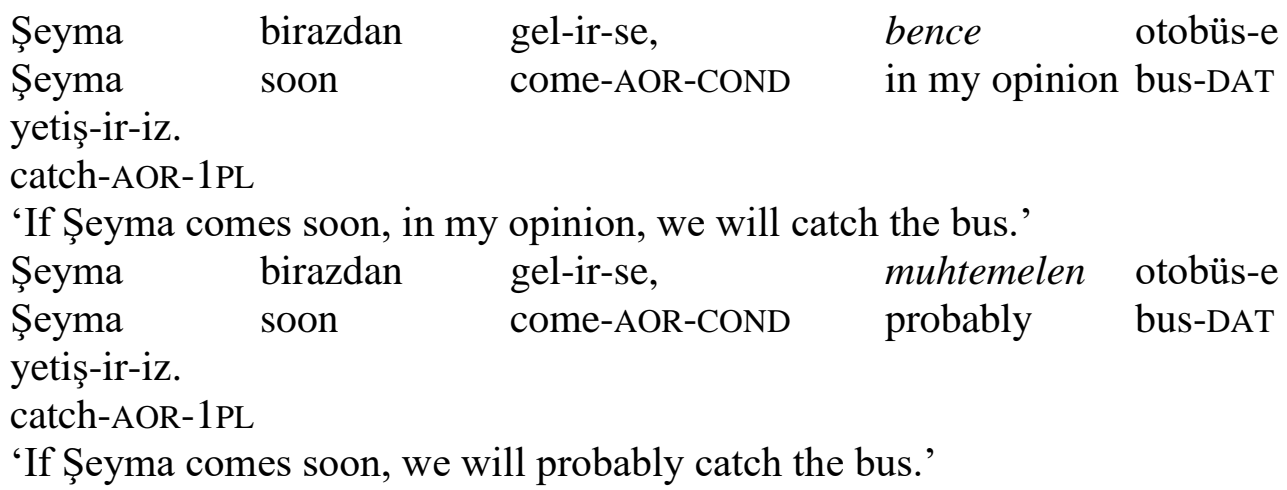

In summary we have seen that the antecedent and consequent clauses hold distinct properties since the former is embedded under the latter (Bhatt \& Pancheva, 2006). As the consequent clause is a matrix clause, the interpretations of the aorist in this context are not expected to be any different from what I argued in the previous section. Nevertheless, its meanings inside an antecedent may not be that easy to identify. Therefore, I dwell on this topic primarily in the upcoming section and explain what kind of readings are allowed for the aorist marker in the antecedent clause of a conditional (henceforth "the antecedent aorist").

4. The restrictions on the interpretation of the antecedent aorist. As I stated earlier, the aorist marker can be interpreted with two main functions (characterizing and future-oriented) in matrix clauses and consequent clauses of conditionals. One can presume that although the antecedent clause is an embedded clause, the aorist can still hold its main interpretations in this context as well, which does not seem to be the case.

4.1. TESTING THE CHARACTERIZING INTERPRETATION OF THE ANTECEDENT AORIST. The aorist can be used interchangeably with the imperfective marker -Iyor in matrix clauses with respect to its characterizing meaning, which is shown by (13) and (14). ${ }^{7}$

Elif her gün koş-ar.
Elif every day run-AOR
'Elif runs every day.'
Paraphrase: It is the characteristic feature of Elif to run every day.
Elif her gün koş-uyor.
Elif every day run-IMPF
'Elif runs every day.'
Paraphrase: It is the characteristic feature of Elif to run every day.

\footnotetext{
${ }^{6}$ See Bhatt and Pancheva (2006) for relevant discussion on the syntactic structure of the conditional statements.

${ }^{7}$ According to Yavaş (1979), the aorist marker and the progressive marker -Iyor do not share the same meaning. She proposes that the aorist marker reports a characteristic of the entity in question while the progressive one just delineates a repeated action of it. Nonetheless, I follow Göksel and Kerslake's (2004) approach and propose that the imperfective marker -Iyor is licensed in characterizing contexts (especially habitual ones) as well as the aorist whereas the aorist marker cannot be used in progressive contexts unlike the imperfective.
} 
The imperfective marker is also compatible with the progressive interpretation as in (15) and the future-oriented interpretation as in (16) in matrix sentences similar to the progressive construction in English.
Elif şu an koş-uyor.
Elif right now run-IMPF
'Elif is running right now.'
Elif yarın maraton-da
Elif tomorrow marathon-LOC
koş-uyor.
run-IMPF
'Elif is running in the marathon tomorrow.'

While the imperfective marker still holds its interpretations inside an antecedent clause, the aorist does not designate a characterizing interpretation in the same environment. Imagine a context where Elif typically goes running to the same park in her neighborhood every day, and I want to introduce a friend of mine to her, and we are all at the same park at that time. While (17) is not felicitous to utter in this context with the intended reading, (18) is.



Not only the characterizing reading but the other readings of the imperfective marker are also still available inside the antecedent clause as (19) and (20) illustrate.

$\begin{array}{llll}\text { Elif şu an } & \text { koş-uyor-sa, } & \text { park-ta-dır. } \\ \text { Elif } & \text { right now } & \text { run-IMPF-COND } & \text { park-LOC-EPIS }\end{array}$

'If Elif is running right now, she must be at the park.'

$\begin{array}{llll}\text { Elif yarın } & \text { maraton-da } & \text { koş-uyor-sa, } & \text { orda tanış-1r-sınız. } \\ \text { Elif tomorrow } & \text { marathon-LOC } & \text { run-IMPF-COND } & \text { there meet-AOR-2PL }\end{array}$

'If Elif is running in the marathon tomorrow, you will meet her there.'

Although I have combined the habitual and generic readings of the aorist under the characterizing interpretation and presented that the characterizing interpretation is not accessible in the habitual context via (17), it might be useful to test the generic environment as in (2) inside an antecedent clause to provide further evidence for my claim. For instance, in a betting context where I am arguing with my friends about whether flamingos are a kind of birds that fly or not and I bet on the side which says that they do not have this feature, I can perfectly utter (22) while (21) would be infelicitous in the same context ${ }^{8}$.
\#Flamingo-lar
uç-ar-sa,
sana
flamingo-PL
fly-AOR-COND
2SG.DAT
kahve al-1r-1m.
coffee buy-AOR-1SG

\footnotetext{
${ }^{8}$ It needs to be stated here that (21) would not be infelicitous by itself but it would not give the intended reading under the discussion.
} 
Unavailable intended reading: If it is the characteristic feature of flamingos to fly, I will buy you a coffee.'
Flamingo-lar
uç-uyor-sa,
sana
kahve al-1r-1m.
flamingo-Pl
fly-IMPF-COND
2SG.DAT
coffee buy-AOR-1SG
Available intended reading: If it is the characteristic feature of flamingos to fly, I will

buy you a coffee.'

As it is evidenced by (21), the characterizing reading is not attainable in generic contexts as well as the habitual ones like (17) inside the aorist marked antecedents even though the intended interpretation can be provided by the imperfective marker as in (18) and (22).

This part basically shows that the aorist marker cannot have the characterizing interpretation in the embedded part of a conditional statement. In the subsequent section, I focus on the futureoriented reading of the aorist marker in the same context and argue that the future-oriented interpretation is also not fully available there.

4.2. TESTING THE FUTURE-ORIENTED INTERPRETATION OF THE ANTECEDENT AORIST. Other than the aorist and the imperfective markers, Turkish has another future-oriented suffix $-A c A k^{9}$, which mainly expresses an event happening in the future in matrix sentences ${ }^{10}$. Therefore, it is considered the "future" marker in Turkish. Although (23), (24), and (25) slightly differ from each other in terms of their interpretations, in a way similar to their English translations, all can be used to talk about the events that are happening in the future (Göksel \& Kerslake, 2005).

\begin{tabular}{lll} 
Şeyma & birazdan & gel-ir. \\
SSeyma & soon & come-AOR \\
\multicolumn{2}{c}{ 'Şeyma will come/comes } & soon.' \\
Şeyma & birazdan & gel-iyor. \\
Şeyma & soon & come-IMPF \\
'Şeyma is coming soon.' & \\
Şeyma & birazdan & gel-ecek. \\
Şeyma & soon & come-FUT \\
'Şeyma is going to come soon.'
\end{tabular}

The imperfective marker keeps all its interpretations inside an antecedent while the aorist does not hold its characterizing reading, as shown in the previous section. This section compares the future-oriented interpretation of the aorist to the future marker -AcAk. As exemplified by (26) and (27), both of these suffixes are allowed in the antecedent of a conditional statement.



\footnotetext{
${ }^{9}$ Yavaş (1979) also compares the aorist marker to -AcAk in terms of their future reference and argues that while the aorist designates a volitional modal, -AcAk suffix is a neutral marker without any modal connotations. As I stated previously, for my current purposes I mainly focus on their interpretations rather than their labels. Therefore, I take both of these markers to be future-oriented.

${ }^{10}$ This marker might have some other interpretations but the future-oriented one is the most basic one.
} 
However, the aorist does not assign the same future-oriented interpretation that the future marker does in this environment. In a context where I just learn that Şeyma will come to a meeting and she lives in a place an hour away from the meeting location and there are fifteen minutes left to the meeting time, I can make the deduction in (29) by using the future marker. However, (28) which is minimally different from (29) in having the aorist marker instead of the future marker, cannot be used in the same context.

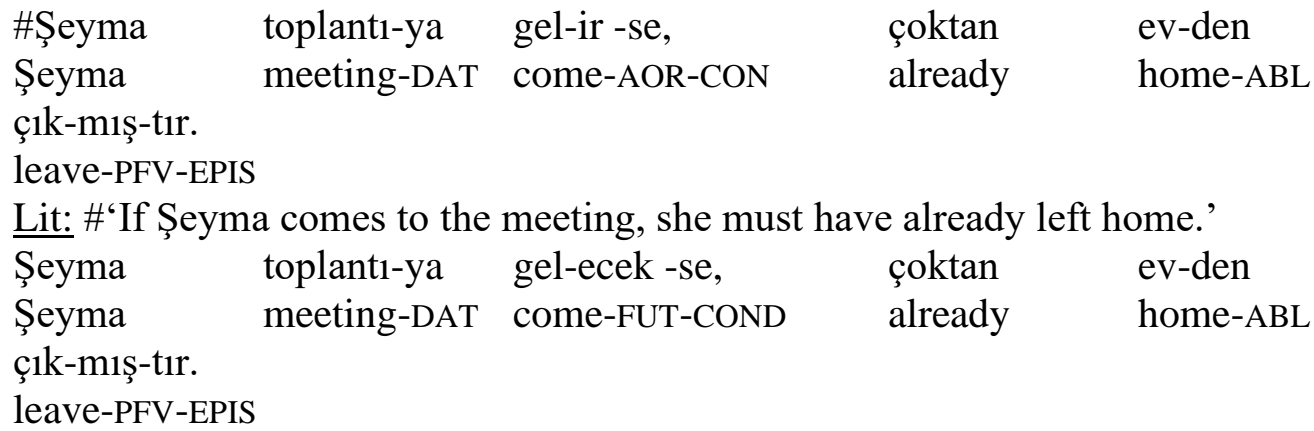

Lit: 'If Şeyma is going to come to the meeting, she must have already left home.'

Even though both of these markers can undoubtedly allow us to talk about the future, only the future marker is licensed here whereas the aorist marker seems to be incapable of adding its future-oriented interpretation.

So far, I have laid out the fact that the aorist does not provide its characterizing interpretation as in (17) and (21) or is not allowed in certain contexts with the future reading as in (28) when it is used in an antecedent clause. On the other hand, the other markers with similar interpretations like the imperfective and the future are licensed for the same contexts with the intended characterizing reading as in (18) and (22) or felicitous to utter with the future-oriented interpretation as in (29). In the following section, I offer a preliminary explanation for the restrictions of the aorist marker and propose that the antecedent aorist is licensed based on the available interpretation in the consequent clause.

5. The initial proposal. What I propose initially is that - following Kratzer's $(1986,1991)$ wellknown restrictor analysis of if-clauses -only when the consequent clause has one of the matrix clause interpretations of the aorist marker is the aorist licensed inside the antecedent clause. Kratzer argues that the conditional sentences are modal sentences whose modal operator is designated by the modal in the consequent clause and the antecedent clause merely restricts the modal base of the consequent modal. This explanation can satisfactorily describe why the aorist marker encounters the restrictions we have identified thus far.

5.1. LICENSING OF THE CHARACTERIZING INTERPRETATION OF THE ANTECEDENT AORIST. In line with my proposal, it is apparent that in the contexts like (30) and (31) in which the consequent clause has the characterizing reading, the aorist marker is acceptable inside the antecedent clause.

Bebek-ler ac1k-1r-sa baby-PL get.hungry-AOR-COND 'If babies get hungry, they usually cry.'

genellikle ağla-r. usually cry-AOR

Available intended reading: In most situations where babies get hungry, it is their characteristic feature to cry.

Ebru erken kalk-ar-sa,

kahvalt1

yap-1yor. 
Ebru early wake.up-AOR-COND breakfast have-IMPF

'If Ebru wakes up early, she has breakfast.'

Available intended reading: In all situations where Ebru wakes up early, it is her characteristic feature to have breakfast.

The characterizing interpretation of the consequent clause in (30) can be evidenced by the availability of the frequency adverb genellikle 'usually' in the consequent part while (31) demonstrates its characterizing reading via the use of the imperfective marker on the main predicate. In both of these examples, nevertheless, as it can be understood from their available intended readings, the aorist does not attain the characterizing interpretation to the antecedent clause per se; it is just $l i$ censed here.

The licensing of the antecedent aorist by the consequent can be illustrated better with the help of a non-characterizing consequent clause and by comparing the aorist and the imperfective markers inside the antecedent one more time. For instance, assume a context where Ebru and I decide to be roommates and I prefer to have a roommate who wakes up early because I do also wake up early. In this case, I can perfectly utter (33) to refer to a future event that is based on Ebru's characteristic behavior whereas (32) cannot yield the given intended reading. Evidently, as the consequent does not have the characterizing reading in this instance, the aorist with the characterizing interpretation cannot be licensed. ${ }^{11}$

\#Ebru erken kalk-ar-sa, iyi anlaş-acağ-1z.

Ebru early wake.up-AOR-COND well get.on-FUT-1PL

Unavailable intended reading: If it is the characteristic feature of Ebru to wake up early, we are going to get on well.

Ebru erken kalk-1yor-sa, iyi anlaş-acağ-1z.

Ebru early wake up-IMPF-COND well get.on-FUT-1PL

Available intended reading: If it is the characteristic feature of Ebru to wake up early, we are going to get on well.

The infelicity of (17) and (21), which are repeated here as (34) and (35) respectively, can be also explained with the same proposal since in both cases the consequent clauses convey the future-oriented interpretation rather than the characterizing one.

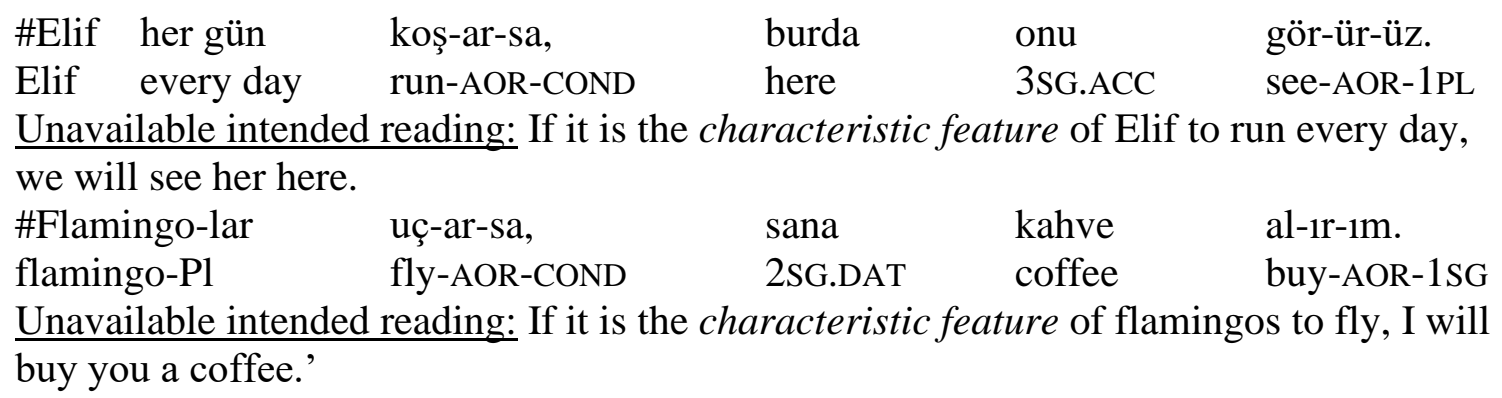

Nonetheless, as stated before, (34) and (35) are not infelicitous sentences because the future-oriented reading in their consequent clauses allows the aorist marker to be used in their antecedents. This is further discussed in what follows.

\footnotetext{
${ }^{11}$ On the other hand, as (32) has a future-oriented reading in the consequent which can license the antecedent aorist, the sentence is not ill-formed. It just does not denote the intended reading. This is further described in the following subsection.
} 
5.2. LICENSING OF THE FUTURE-ORIENTED INTERPRETATION OF THE ANTECEDENT AORIST. Similar to the licensing of the antecedent aorist when the consequent has the characterizing interpretation, if the consequent part has the future-oriented reading, the antecedent allows the use of the aorist inside the clause, as represented by (36) and (37).

$\begin{array}{lllll}\text { Ela parti-ye } & \text { gel-ir-se, } & \text { yarın } & \text { onunla } & \text { tanış-1r-sın. } \\ \text { Ela party-DAT } & \text { come-AOR-COND } & \text { tomorrow } & \text { 3SG.COM } & \text { meet-AOR-2SG } \\ \text { 'If Ela comes to the party, you will meet her.' } & & \\ \text { Ela parti-ye } & \text { gel-ir-se, } & \text { onunla } & \text { tanış-acak-sin. } \\ \text { Ela party-DAT } & \text { come-AOR-COND } & \text { 3SG.COM } & \text { meet-FUT-2SG }\end{array}$

The future-oriented reading of the consequent in (36) can be justified by the future-oriented time adverbial yarın 'tomorrow' and the future marker overtly demonstrates the future reference in the consequent of (37).

On the other hand, if the consequent clause does not have a future-oriented interpretation like in (38), its antecedent cannot license the aorist marker while the use of the future marker is highly acceptable in the same context as in (39).
\#Ela parti-ye
gel-ir-se,
şimdi hazırlan-1yor-dur.
Ela party-DAT
come-AOR-COND
now get.ready-IMPF-EPIS
Lit: \#'If Ela comes to the party, she must be getting ready now.'

$\begin{array}{llll}\text { Ela parti-ye } & \text { gel-ecek-se, } & \text { şimdi hazırlan-1yor-dur. } \\ \text { Ela party-DAT } & \text { come-AOR-COND now get.ready-IMPF-EPIS }\end{array}$
Lit: 'If Ela is going to come to the party, she must be getting ready now.'

This can also explain the infelicity of (28), which is replicated here in (40).

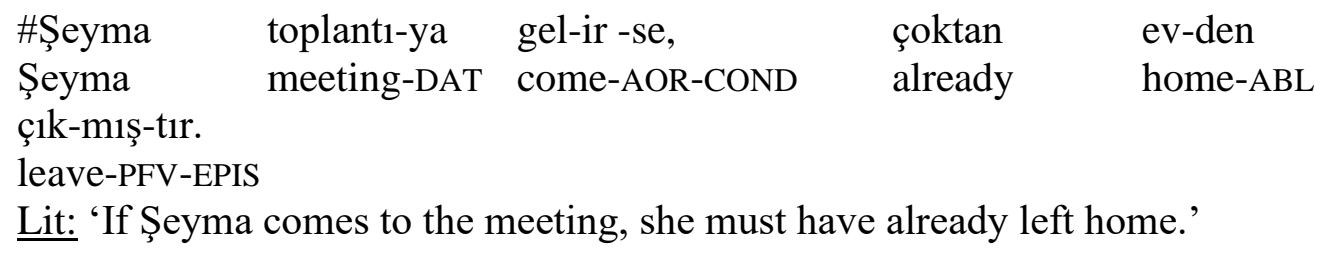

In both (38) and (40), the consequent clause makes an epistemic claim about what might be happening now or what might have happened until now respectively. In either case, as there is no future-oriented reading available for the consequent part, these sentences cannot license the antecedent aorist marker. Notwithstanding, some cases appear to assign neither the future-oriented nor the characterizing interpretation to their consequent clause and yet allow the usage of the antecedent aorist. The next part reveals these cases, and the final proposal will try to accommodate these additional observations, as well.

5.3. THE CHALLENGES. I have argued that in order to license the antecedent aorist, the consequent clause must have one of its matrix clause interpretations. However, even when the consequent clause does not seem to have either of these interpretations, the aorist is still acceptable in the antecedent part in some situations, which creates a problem for my initial proposal.

For instance, although there is no future-oriented marker in the consequent part of (42) just like (41), it still licenses the antecedent aorist unlike (41). It is possible to utter (42) in a context where I know Şeyma is not on speaking terms with Gül for a while and she only shares pictures with her friends if she is talking to them. 


\begin{tabular}{|c|c|c|c|}
\hline $\begin{array}{l}\text { \#Şeyma } \\
\text { Şeyma } \\
\text { çık-mış-tır. } \\
\text { leave-PFV-EPIs }\end{array}$ & $\begin{array}{l}\text { toplant1-ya } \\
\text { meeting-DAT }\end{array}$ & $\begin{array}{ll}\text { gel-ir -se, } & \text { çoktan } \\
\text { come-AOR-COND } & \text { already }\end{array}$ & $\begin{array}{l}\text { ev-den } \\
\text { home-ABL }\end{array}$ \\
\hline Lit: 'If Şeyma & comes to the 1 & neeting, she must have already lef & me.' \\
\hline Şeyma & Gül'le & paylaş-1r-sa, & onu \\
\hline $\begin{array}{l}\text { Şeyma } \\
\text { affet-miş-tir. } \\
\text { forgive-PFV-EI }\end{array}$ & Gül.cOM & share-AOR-COND & 3SG.ACC \\
\hline
\end{tabular}

Analogous to the difference between (41) and (42) in terms of allowing the antecedent aorist, there is a discrepancy between (43) and (44) despite the exact same morphology on their consequent verbs. Even though the deduction in (43) cannot be uttered due to not having a futureoriented consequent, (44) is highly acceptable to say in spite of lacking the future-oriented interpretation in the consequent.

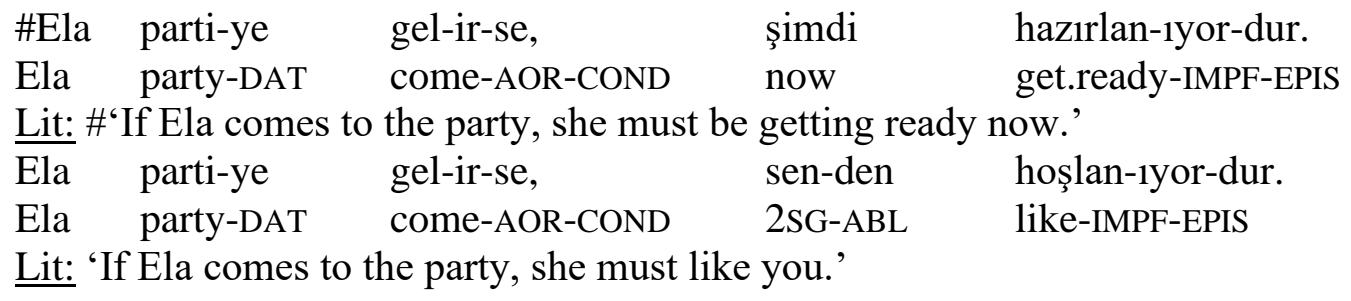

Moreover, it is possible to use the antecedent aorist when making an inference with nominal predicates as in (45), which is similar to (44) with respect to its meaning. It could be presumed that both (44) and (45) have the characterizing interpretation and that is why they allow the antecedent aorist, yet it is not the case for either of them.

$$
\begin{aligned}
& \text { Ela parti-ye gel-ir-se, } \\
& \text { Ela party-DAT come-AOR-COND 2SG.DAT } \\
& \text { Lit: 'If Ela comes to the party, she must be in love with you.' }
\end{aligned}
$$

Additionally, one can assume that as hoşlan- 'to like' and aşık 'in love' are stative predicates and hazırlan 'to get ready' is an action verb, this might be something related to the stativity of the main predicates. However, in the case of (41) and (42) both of their consequent verbs are action verbs.

Alternatively, all the challenges discussed so far might be linked to the epistemic marker -DIr. As it is evident in (41) - (45), all those instances happen to have the epistemic marker and it might be considered that the interpretation of this marker may have an effect on these challenging examples. Nonetheless, there are consequent clauses that have neither the epistemic marker nor any of the interpretations of the aorist marker and yet still license the antecedent aorist, as shown by (46) and (47).
Elif'i
Elif.ACC
gör-ür-sen,
see-AOR-COND-2SG
Lit: 'If you see Elif, give this book.'
Elif' $\mathrm{i}$
Elif.ACC see-AOR-COND-2SG




\section{Lit: 'If you see Elif, you should talk to her.'}

The example in (46) shows a consequent clause with the imperative and (47) with the obligative. Neither of these seem to have either the characterizing or the future-oriented interpretations of the aorist but even so, they let the use of the antecedent aorist.

Considering all these, I diverge from my initial proposal and change my perspective to be able to bring a better explanation for these issues. In my final proposal, I argue that inspired by Schulz (2008), instead of the consequent clause licensing the antecedent aorist, the antecedent aorist sets the evaluation time of the consequent to the worlds that are compatible with the interpretations of the aorist. The next section discusses the details of this proposal and demonstrates how all these challenges can be accounted for by this new version.

6. The final proposal. Before I discuss my updated proposal, I will first briefly summarize Schulz's (2008) analysis. Schulz (2008) analyzes the tenses in conditionals as non-deictic, evaluated relative to the local evaluation time, based on the proposal by Abusch (1997). Schulz states that the local evaluation time might differ from the utterance time in the scope of intentional operators, in this case - the conditionals. She uses two time parameters to describe the tenses: the denotation time and the anchor. The denotation time can be described as the time of the eventuality, and it is relativized to the anchor of a tense. Schulz (2008) argues that the Simple Present in English has the non-pastness interpretation and hence it can select a future denotation time instead of the utterance time although it is the present tense. Combining these ideas, she suggests that when the Simple Present selects the future denotation time in the antecedent of a conditional, it can shift the evaluation time ${ }^{12}$ of the consequent from the utterance time to the future. She claims that this shift can only take place if the denotation time of the antecedent is the future. However, according to her, the future shift on the consequent is not compulsory.

I adapt Schulz's (2008) analysis for the Simple Present in the antecedent of conditionals to the antecedent aorist in my case. As the aorist marker in Turkish is regarded as similar to the Simple Present in English (Kornfilt, 1997), this kind of similarity between them can be expected. However, I expand her claims and propose that the denotation time of the antecedent aorist sets the evaluation time of the consequent clause. In other words, if the antecedent aorist chooses its denotation time as the future (i.e., the future-oriented reading), the future shift in the evaluation time of the consequent clause is obligatory. Schulz (2008) exemplifies this as in (48), which is example (13) in her study. In both (48) and (49), its direct translation in Turkish, the Simple Past or the perfective marker in the consequent denotes a time before the denotation time of the antecedent, which is the future, not before the utterance time of the statement.

If he comes out smiling, the interview went well.

\begin{tabular}{|c|c|c|}
\hline $\begin{array}{l}\text { Gülerek } \\
\text { smiling }\end{array}$ & $\begin{array}{l}\text { çık-ar-sa, } \\
\text { come out-AOR-COND }\end{array}$ & $\begin{array}{l}\text { görüşme } \\
\text { interview }\end{array}$ \\
\hline
\end{tabular}

'If s/he comes out smiling, the interview went well.'
(Schulz, 2008, p. 706)

go-PF-EPIS

Schulz (2008) bases her discussion on possibilities, world-time pairs, rather than possible worlds. In this way, when the denotation time of the possibility is shifted, the worlds that are

\footnotetext{
${ }^{12}$ Schulz (2008) mostly uses the term "anchor" for this context, but I prefer to use the term "evaluation time" for the same meaning. I take this term to mean that the aspects of events (progressive, perfective, prospective) are evaluated relative to this reference point. In this case, the evaluation time and the event time do not necessarily coincide with each other. To illustrate, if the event time is past, this can be evaluated relative to a future reference point or a past reference point, as well as the point of utterance.
} 
compatible with it are shifted in the same direction. However, she also suggests that when the modal base is epistemic, not ontic ${ }^{13}$, the future shift for the consequent does not occur. I argue that this is not the case in Turkish. Once the denotation time of the antecedent is shifted to the future, the consequent cannot be evaluated relative to the utterance time even in epistemic claims. This can be shown better with the examples (41) and (42), which are repeated here as (50) and (51) respectively. The adverb çoktan 'already' in (50) anchors to the utterance time. Therefore, (50) demonstrates an example where the perfective marker in the consequent takes its evaluation time as the utterance time and refers to the possibilities before that time. However, as the antecedent aorist chooses its denotation time as the future, the possibilities where Şeyma comes to the meeting, the consequent cannot make a claim relative to the utterance time anymore. Hence, the sentence is infelicitous. On the other hand, in (51), the evaluation time of the consequent is in accordance with the denotation time of the antecedent aorist, which involves the future possibilities in which Şeyma shares a picture with Gül. The perfective marker in (51) is evaluated relative to that future time and denotes the times before it, not before the utterance time.

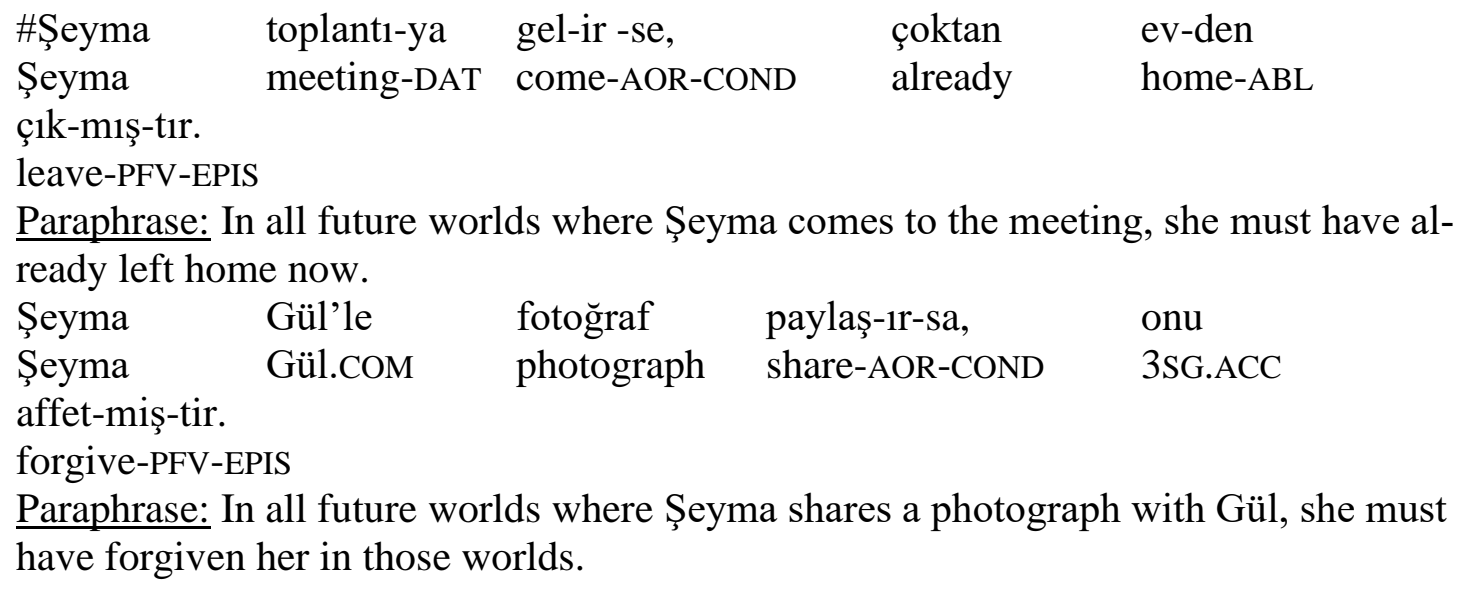

This fact applies to all the other challenging examples in the previous section as well. Although the examples (44) and (45), repeated in (52) and (53), seem to counter my proposal, they are also evaluated relative to the future denotation of the antecedent. Nevertheless, it appears that they are understood as true at the utterance time, which is just an implication since it can be cancelled as in (54) and (55). This peculiar behavior seems to be restricted to stativity. However, I need to leave an analysis of these puzzling facts concerning stative predicates to future work.

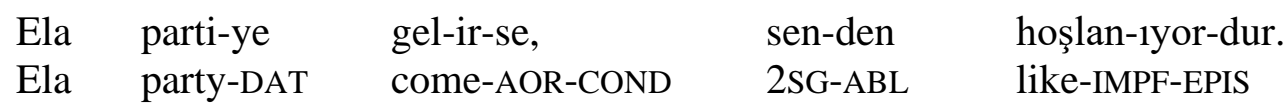

Paraphrase: In all future worlds where Ela comes to the party, she likes you.

$\begin{array}{lllll}\text { Ela } & \text { parti-ye } & \text { gel-ir-se, } & \text { sana } & \text { aşık-tır. } \\ \text { Ela } & \text { party-DAT } & \text { come-AOR-COND } & \text { 2SG.DAT } & \text { in.love-EPIS }\end{array}$

Paraphrase: In all future worlds where Ela comes to the party, she is in love with you.

$\begin{array}{lllll}\text { Ela sen-den } & \text { hoşlan-m-1yor, } & \text { ama } & \text { parti-ye } & \text { gel-ir-se, } \\ \text { Ela 2SG-ABL like-NEG-IMPF } & \text { but } & \text { party-DAT } & \text { come-AOR-COND } \\ \text { sen-den } & \text { hoşlan-1yor-dur. } & & & \end{array}$

\footnotetext{
13 Schulz (2008) suggests a modal base called "ontic" in her analysis and she argues that only when this modal base is chosen might the future shift happen in the consequent, which I do not agree with.
} 
2SG-ABL like-IMPF-EPIS

'Ela does not like you but if she comes to the party, she likes you.'

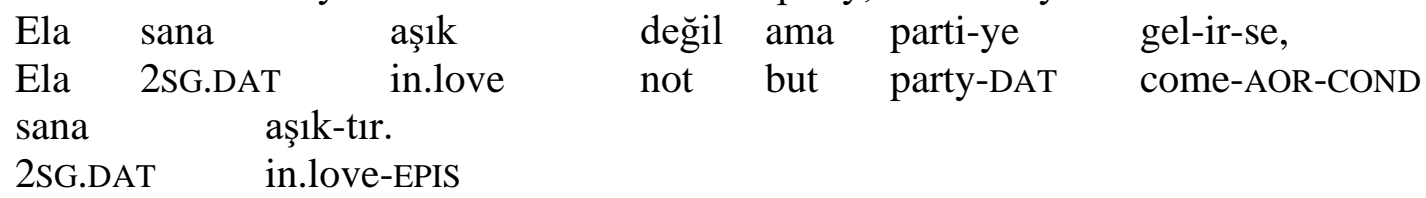

'Ela is not in love with you but if she comes to the party, she is in love with you.'

Other than the future denotation, the aorist has another function that is related to its characterizing interpretation. The characterizing reading of the aorist can be analyzed as "quantification over situations ${ }^{14 "}$ more specifically "quantification over minimal situations ${ }^{15}$ " in line with von Fintel's (1994) proposal for adverbial quantification. He argues that the frequency adverbs denote this quantification in conditional statements. Since the frequency adverbs are allowed with the characterizing interpretation of the aorist, this analysis can be implemented for explaining the characterizing interpretation of the antecedent aorist in our case. As it is seen from (56), the antecedent aorist allows the characterizing reading, evidenced by the frequency adverb genellikle 'usually' there, but it just makes a quantification over the situations without any specific time restriction.
Ebru genellikle erken
kalk-ar-sa,
kahvalt1
yap-ar.
Ebru usually early
wake.up-AOR-COND
breakfast
have-IMPF

Paraphrase: In most situations where Ebru wakes up early, it is her characteristic feature to have breakfast.

Furthermore, when the antecedent aorist denotes a quantification over situations, in other words when it has the characterizing reading, it only licenses the characterizing interpretation for its consequent clause. It does not even allow the future-oriented interpretation or any others as we may remember from (32), provided here one more time in (57).
\#Ebru genellikle erken
kalk-ar-sa,
iyi anlaş-acağ-1z.
Ebru usually
early
wake.up-AOR-COND well
get.on-FUT-1PL

Unavailable paraphrase: In most situations where Ebru wakes up early, we are going to get on well.

My future shift and quantificational proposals only work for the antecedent aorist because the other markers, namely the imperfective -Iyor and the future marker-AcAk, can neither set the denotation time to the future - it always stays as the utterance time - nor make a quantification over situations. They add their own interpretation to the antecedent clause directly, but they do not influence the evaluation of the consequent clause. We can realize this from the paraphrases of (58) and (59), which are the replications of (33) and (39) respectively.

$$
\begin{array}{lllll}
\text { Ebru } & \text { erken } & \text { kalk-ıyor-sa, } & \text { iyi } & \text { anlaş-acağ-1z. } \\
\text { Ebru } & \text { early } & \text { wake up-IMPF-COND } & \text { well } & \text { get.on-FUT-1PL }
\end{array}
$$

\footnotetext{
${ }^{14}$ What von Fintel (1994) refers to as "situations" seems similar to what Schulz (2008) means by the term "possibilities".

15 von Fintel (1994, p. 18) states that "the minimal situations in a set of situations, i.e., in a proposition, are those that do not have proper parts that are also in the set.". However, for my current purposes, I do not focus on this specification.
} 
Paraphrase: In all present worlds where it is the characteristic feature of Ebru to wake up early, we are going to get on well.

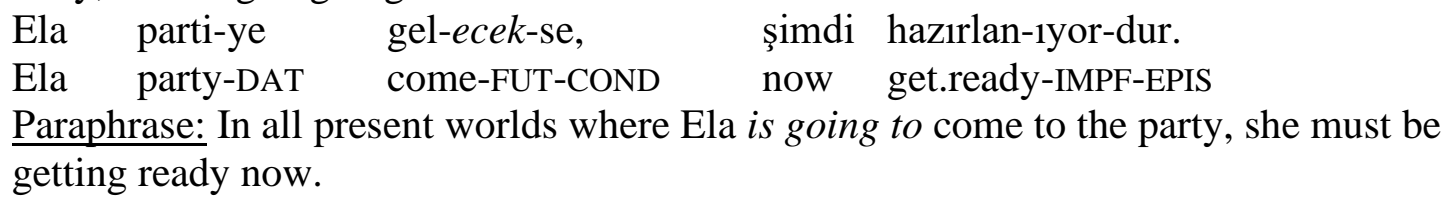

All in all, the only marker that can set the denotation time to the future or make a quantification over situations is the aorist and if there is a mismatch between the denotation of the antecedent aorist and the interpretation of the consequent, the statement is infelicitous.

7. Discussion and conclusion. In summary, I have illustrated that the aorist has two main interpretations in matrix sentences, namely the characterizing and the future-oriented ones. I have argued that the antecedent aorist behaves differently from its counterpart in the consequent clause since it surfaces in an embedded context by being inside an antecedent. I subsequently demonstrate what kind of differences or restrictions the antecedent aorist has by comparing it to the imperfective and the future markers in the same contexts for its characterizing and future-oriented interpretations, respectively. Based on these restrictions, I make a preliminary proposal by stating that the antecedent aorist is licensed only if the consequent clause has one of its matrix clause interpretations following Kratzer's $(1986,1991)$ restrictor analysis of conditionals. However, we have seen some counter-examples for this initial proposal. In some cases, the antecedent aorist is allowed for certain epistemic deductions, but it is not licensed by some others even though their syntactic structures are seemingly the same. Moreover, the consequent clauses with the imperative or the obligative marker let the use of the antecedent aorist as well. In order to better explain all these challenging situations, I have revised the proposal in line with Schulz's (2008) analysis of the Simple Present in conditional antecedents. I have argued that the antecedent aorist can have a denotation time referring to the future instead of the utterance time, unlike the imperfective and the future markers. Thus, it changes the evaluation time of the consequent from the utterance time to the denoted future time in the antecedent. Furthermore, based on von Fintel's (1994) analysis, I argue that if the aorist makes a quantification over situations with its characterizing interpretation, it only licenses the characterizing reading for the consequent clause as well. Finally, while the aorist can change the denotation time from the utterance time to the future, the other markers like the imperfective and the future cannot do so. They are always evaluated relative to the utterance time and can add their interpretation directly inside the antecedent clause, unlike the aorist. In short, the aorist selects its denotation either as the future time and evaluates the consequent based on this future time or as the quantification over situations and requires the use of the characterizing interpretation in the consequent.

\section{References}

Abusch, Dorit. 1997. Sequence of tense and temporal de re. Linguistics and Philosophy 20. 1-50. Bhatt, Rajesh \& Roumyana Pancheva. 2017. Conditionals. In Martin Everaert and Henk van Riemsdijk (eds.), The Wiley Blackwell Companion to Syntax, Second Edition. https://doi.org/10.1002/9781118358733.wbsyncom119.

Cinque, Guglielmo. 2001. A note on mood, modality, tense, and aspect affixes in Turkish. In Eser Erguvanlı Taylan (eds.), The verb in Turkish. 47-59. Amsterdam: John Benjamins. https://doi.org/10.1075/la.44.03cin. 
von Fintel, Kai. 1994. Restrictions on quantifier domains. Amherst, MA: University of Massachusetts Amherst dissertation.

Göksel, Aslı \& Celia Kerslake. 2005. Turkish: A comprehensive grammar. New York: Routledge.

Kornfilt, Jaklin. 1997. Turkish. New York: Routledge.

Kratzer, Angelika. 1986. Conditionals. Chicago Linguistics Society 22(2). 1-15.

Kratzer, Angelika. 1991. Modality. In Arnim von Stechow \& Dieter Wunderlich (eds.), Semantics: An international handbook of contemporary research. 639-650. Berlin: de Gruyter.

Shulz, Katrin. 2008. Non-deictic tenses in conditionals. Proceedings of Semantics and Linguistic Theory (SALT) 18. 694-710. https://doi.org/10.3765/salt.v18i0.2498.

Soykan, Bergül. 2021. A semantic description of Turkish conditionals. İstanbul: Boğaziçi University thesis.

Yavaş, Feryal. 1979. The Turkish aorist. Kansas Working Papers in Linguistics 4(1). 41-49. https://doi.org/10.17161/KWPL.1808.656. 